\title{
Research on Innovation and Entrepreneurship Education and Professional Education Quality of Higher Vocational Teachers under the Background of Engineering
}

\author{
Wang Juan ${ }^{1, *}$, Zhang Zhentao $^{2}$ \\ ${ }^{1}$ School of Electrical and Information Technology, The Chinese University of Jilin Vocational College of Industry and \\ Technology, Jilin, China \\ ${ }^{2}$ College of Information and Control Engineering, The Chinese University of Jilin Institute of Chemical Technology, \\ Jilin, China \\ *Corresponding author. Email: juan8302@126.com
}

\begin{abstract}
This research is based on the perspective of promoting the professionalization of engineering higher vocational teachers, according to the professional characteristics, which investigates the professional quality of teachers in higher vocational colleges. The exploration of teachers' professional quality, taking the professional development and teachers' team construction of higher vocational education as the breakthrough point, analyzes the particularity of engineering development, and selects the quality elements of higher vocational teachers according to the development status of higher vocational teachers' quality, so as to provide reference for the organic integration of innovation and entrepreneurship education and professional education. From the perspective of engineering specialization, the cultivation and improvement of professional quality of innovation and entrepreneurship teachers in higher vocational colleges is a coherent and sustainable integration process. Higher vocational teachers can realize the entrepreneurship and innovation ability under the background of engineering professional education, which will enable teachers to provide more innovation and entrepreneurship tools for students. The complete team of teachers plays a positive role in cultivating students' healthy quality of innovation and entrepreneurship, and can promote the development and practice of innovation and entrepreneurship education.
\end{abstract}

Keywords: higher vocational teachers' quality, engineering specialization, innovation and entrepreneurship.

\section{INTRODUCTION}

With the accelerating pace of economic structural adjustment, the traditional industries and positions will be restructured, and new industries, new industries and new types of jobs will continue to emerge. The cultivation of modern talents with innovative thinking, innovative spirit, entrepreneurial awareness and entrepreneurial ability will become an important factor in helping economic development and transformation in China.

Innovation and entrepreneurship education should be traced back to entrepreneurship education. In 1998, the first college students' Entrepreneurship plan competition was held in Tsinghua University. In 2003, the Ministry of education of China launched pilot education activities on entrepreneurship in nine colleges and universities, which opened the prelude of college students' entrepreneurship education. In 2010, the document "opinions of the ministry of education on vigorously promoting innovation and entrepreneurship education in colleges and universities and college students' independent entrepreneurship work" mentioned that "innovation and entrepreneurship education" marks the beginning of the transformation from "entrepreneurship education" to "innovation and entrepreneurship education", advocating the concept of innovation and entrepreneurship, popularizing the knowledge of innovation and entrepreneurship, and leading the behavior of innovation 
and entrepreneurship [1]. To deepen the integration of industry and education and promote the precise reform of vocational education, it is specifically pointed out that the industrial demand-side structure should be integrated with the supply-side structure of talent training, and a large number of innovative and entrepreneurial talents should be trained [2].

The integration practice of entrepreneurship education and professional education in foreign countries is earlier, and the innovative professional education in the United States is gradually forming a complete teaching research and implementation system. This paper summarizes that one of the important directions of teaching reform in European and American universities is how to effectively integrate innovation and entrepreneurship education into professional education [3]. In order to train college students to become professional and innovative talents with entrepreneurial ability, we need to integrate the corresponding innovative ideas and entrepreneurial awareness, and entrepreneurial technology into the professional teaching. In the United States, the integration of professional education and entrepreneurship education is promoted by the transformation of economic driven mode. Entrepreneurship education should become a basic training content for teachers in the future, so that teachers can consciously infiltrate entrepreneurship ideas into students in the future teaching. The key to the integration of innovation and entrepreneurship education and professional education must consider the differences and applicability in different disciplines [4]. Research scholars have carried out research and analysis on the influencing factors of entrepreneurship, and put forward the view that the formation of entrepreneurship teachers and the educational environment of students have a greater impact on the educational effect [5]. There are few restrictions on teacher assessment in foreign countries, which focus on teachers' practical ability, innovation ability and entrepreneurial ability [6].

The research on the comprehensive quality of teachers' professional education and innovation and entrepreneurship education in higher vocational colleges is conducive to the cultivation of students' comprehensive quality. The formation of a new high-quality teaching team not only provides a strong support for the cultivation of college students' innovation and entrepreneurship ability, but also is the only way to deepen the integration reform of innovation and entrepreneurship education and professional education in higher vocational colleges.

\section{RESEARCH DESIGN RESEARCH ON TEACHERS' QUALITY}

This study from the three levels of on-the-job skill, practice, innovation and entrepreneurship, according to the four dimensions of teaching and research ability, cocreation ability, cognition of innovation and entrepreneurship, engineering specialty innovation integration ability and personal characteristics, which analyses the quality of " integration of specialty and innovation" of higher vocational engineering innovation and entrepreneurship teachers in Table 1.

Table 1. The quality of teachers' professional education and innovation and entrepreneurship education

\begin{tabular}{|c|c|c|}
\hline Arrangement & Dimension & Target \\
\hline \multirow{10}{*}{$\begin{array}{l}\text { On-the-job } \\
\text { skill }\end{array}$} & \multirow{10}{*}{$\begin{array}{l}\text { Teaching } \\
\text { and } \\
\text { research } \\
\text { ability }\end{array}$} & Teaching inspiration ability \\
\hline & & Ability to teach students in accordance with their aptitude \\
\hline & & Observation and analysis ability \\
\hline & & Evaluate feedback capability \\
\hline & & Transformation ability of scientific research achievements \\
\hline & & Design of Teaching and evaluation ability \\
\hline & & Teaching reflection ability \\
\hline & & Ability to use teaching methods \\
\hline & & Scientific research and innovation ability \\
\hline & & Literature reading ability \\
\hline \multirow{7}{*}{ Practice } & \multirow{7}{*}{$\begin{array}{l}\text { Cocreation } \\
\text { ability }\end{array}$} & The ability to teach middle school \\
\hline & & The ability of combining theory with practice \\
\hline & & The ability to integrate resources \\
\hline & & Ability to solve engineering problems \\
\hline & & Resource development capability \\
\hline & & Entrepreneurial experience \\
\hline & & Basic professional quality \\
\hline \multirow[b]{3}{*}{ Innovation } & \multirow{3}{*}{$\begin{array}{l}\text { Cognition of innovation } \\
\text { and entrepreneurship }\end{array}$} & Awareness of innovation and Entrepreneurship \\
\hline & & Innovation and Entrepreneurship \\
\hline & & Innovation and entrepreneurship identity \\
\hline
\end{tabular}




\begin{tabular}{|c|c|c|}
\hline \multirow{3}{*}{$\begin{array}{c}\text { and } \\
\text { entrepreneurship }\end{array}$} & creative thinking \\
\cline { 3 - 3 } & & Innovation and entrepreneurship psychology \\
\cline { 2 - 3 } & $\begin{array}{c}\text { Engineering specialty } \\
\text { innovation integration } \\
\text { ability }\end{array}$ & Integration ability of subject knowledge \\
\cline { 3 - 3 } & & Planning and organizational capabilities \\
\cline { 3 - 3 } & & Exploration and development capability \\
\hline
\end{tabular}

\section{OPTIMIZATION STRATEGY}

This paper puts forward the strategies to optimize the quality of engineering professional innovation and entrepreneurship teachers from the following seven aspects.

\subsection{Based on Career Development Planning Professional Quality}

Professional innovation and entrepreneurship teachers can receive training through the training mode of "on-site and network complementary", the use of network information technology to provide micro class and other network teaching and training courses. As teachers, they should also participate in automation innovation and entrepreneurship related meetings in their spare time to master the current research hotspots. Every teacher must receive education and social experience alternately, and constantly regress and metabolize each other. This kind of "cyclical cycle" of education and experience can make teachers constantly update their professional knowledge, make the knowledge of innovation and entrepreneurship teachers become "living water with source", highlight teachers' sense of achievement, prevent job burnout, and help to obtain the sense of innovation.

\subsection{Professional Quality Based on Teaching Content}

Innovation and entrepreneurship teachers should have the ability of subject knowledge integration. Through the integration of multi-disciplinary knowledge, resources and means to achieve teaching objectives, so as to cultivate students' comprehensive quality of innovation and entrepreneurship.

Teachers should make it clear that professional subjects are the main courses, and other subjects are just tools and means for students to learn knowledge, in order to enrich students' knowledge and broaden their horizons.

Teachers should improve their ability to use various teaching resources, such as flipped classroom. In order to make better use of the ability of subject knowledge fusion, teachers should keep communication and learning. Teachers can naturally infiltrate the knowledge of other disciplines into the automation major, and can use a variety of teaching tools to display and focus on communication skills.

\subsection{Professional Quality Based on Teaching Method}

In the aspect of educational knowledge learning, innovation and entrepreneurship teachers of engineering specialty should also supplement the latest teaching methods in time. In the selection of research activities, we should choose the learning content and form of targeted training, and timely supplement the "professional teaching theory" and "professional teaching method".

\subsubsection{Trainer Skills}

Innovation and entrepreneurship education is the expansion and continuation of scientific research project training. The innovation and entrepreneurship teachers of engineering specialty should skill-fully use the trainer technology to stimulate students' innovation and entrepreneurship potential, increase students' learning motivation, and better master all kinds of professional knowledge and skills. Trainer technology can not only enrich and make up for the lack of entrepreneurship education theory, but also provide teaching tools for entrepreneurship teachers in practice teaching, provide accurate entrepreneurship guidance for students, so as to improve the success rate of students' entrepreneurship.

\subsubsection{Co-creation of Teachers and Students}

In terms of the ability to integrate resources, in the process of co-creation with students, innovation and entrepreneurship teachers should help students identify the surrounding resources, and be able to identify and select, absorb and allocate resources from different sources, different levels, different structures and different contents, so as to improve the efficiency of entrepreneurship and promote students' thinking ability.

In terms of the ability of cooperation between teachers and students and professional quality, teachers and students can carry out reasonable division of labor and cooperation, including knowledge, resources, technology, information and other aspects of cooperation, in order to achieve the expected.

\subsection{Based on the Construction of Learning Community Professional Quality}

Teachers should learn from each other and share experience, improve their learning level, and have a more harmonious relationship with other teachers, which can 
stimulate "the interest of exploring other teachers' teaching practice", and teachers can also experience satisfaction in the collective wisdom.

In terms of the professional quality of alumni resources development, automation professional innovation and entrepreneurship teachers should have the ability of alumni resources development, make full and reasonable use of alumni resources, including information resources, intellectual resources, educational resources and material resources, so as to improve students' entrepreneurial enthusiasm.

\subsection{Reflection on Professional Quality Based On Innovative Experience}

The environment of innovation and entrepreneurship is changing all the time. In the process of co-creation between teachers and students, entrepreneurial teachers should constantly learn and reflect, and accumulate teaching knowledge and experience, so as to better guide students' entrepreneurial projects.

\subsection{Based on Teachers' Scientific Research Professional Quality}

Higher vocational automation professional innovation and entrepreneurship teachers participate in the development, utilization and promotion of "new products", "new technology", "new process" , who can participate in the transformation of scientific and technological achievements, technological transformation, specific technological innovation, and serve the enterprise. In terms of the professional quality of the transformation of scientific research achievements, innovation and entrepreneurship teachers should have the ability of transformation of scientific research achievements when guiding college students' scientific research and entrepreneurship training, which can not only promote the progress of science and technology, but also cultivate students' innovative spirit and entrepreneurial ability in the process of transformation of scientific research achievements.

\subsection{Based on Enterprise Practice Professional Quality}

For the particularity of engineering enterprises, the visit and practice of innovation and entrepreneurship teachers in enterprises is conducive to the rapid transformation of teachers' experience accumulation in the real professional environment into professional education and teaching resources for transmission, which is conducive to the teachers to grasp the needs of enterprises and the opportunity of innovation and entrepreneurship.

\section{CONCLUSION}

Teachers in higher vocational colleges should make students master basic professional skills, enhance entrepreneurial awareness, improve employment skills, change employment thinking, promote students' all-round development and improve their comprehensive quality.

Through the optimization strategy of teachers' professional quality, we can promote the organic integration of innovation and entrepreneurship education and automation education.

Teachers are the leading force in the reform of innovative professional education. From the perspective of teachers' professional quality, we can promote the integration of innovation and entrepreneurship education and professional education, promote and encourage each other, and truly solve the problem of teachers in innovation and entrepreneurship education and professional education.

\section{ACKNOWLEDGMENTS}

This paper is one of the phased achievements of the teaching reform research project of vocational education and adult education in Jilin Province "Research on multi dimensional professional quality of higher vocational teachers from the perspective of integration of innovation and entrepreneurship education and automation education" (NO.2020ZCY120).

\section{REFERENCES}

[1] Ye JIA. Research on Innovation and Entrepreneurship Education Policyand its Implementation Effect in Universities of JiangXi Province [D]. Jiangxi University of Finance and Economics, 2020.

[2] Gibb, A. (2007), "Entrepreneurship: unique solutions for unique environments. Is it possible to achieve this with the existing paradigm?", International Journal of Entrepreneurship Education, Vol. 5, pp. 93-142

[3] Katz,J. A. The Chronology and Intellectual Trajectory of American Entrepreneurship Education[J]. Jour-nal of Business Venturing,2003,18(2):283-300

[4] Ren Yongli. Research on the integration path of entrepreneurship education and professional education in Colleges and Universities [J]. Chinese Journal of Education,2015(2):53-54

[5] Salter A J, Mckelvey M. Evolutionary analysis of innovation and entrepreneurship: Sidney G. Winterrecipient of the 2015 Global Award for Entrepreneurship Research[J]. Small Business Economics, 2016, 47(1):1-14.

[6] Davey T, Rossano S, Sijde P V D. Does context matter in academic entrepreneurship? The role of barriers and drivers in the regional and national context[J]. Journal of Technology Transfer, 2016, 41(6):1457-1482. 